\title{
Front Matter: Volume 8913
}

, "Front Matter: Volume 8913," Proc. SPIE 8913, International Symposium on Photoelectronic Detection and Imaging 2013: Optical Storage and Display Technology, 891301 (26 August 2013); doi: 10.1117/12.2044136

SPIE Event: ISPDI 2013 - Fifth International Symposium on Photoelectronic SPIE. Detection and Imaging, 2013, Beijing, China 


\title{
International Symposium on Photoelectronic Detection and Imaging 2013
}

\section{Optical Storage and Display Technology}

\author{
Changsheng Xie \\ Yikai Su \\ Liangcai Cao \\ Editors
}

\section{5-27 June 2013 \\ Beijing, China}

\section{Organized by}

Photoelectronic Technology Committee, Chinese Society of Astronautics • Tianjin Jinhang Institute of Technical Physics (China) - Science and Technology on Low Light Level Night Vision Laboratory (China) - Science and Technology on Optical Radiation Laboratory (China) • Science and Technology on Electromagnetic Scattering Laboratory (China)

Sponsored by

SPIE • The Optical Society • European Optical Society • Chinese Society of Astronautics

Published by

SPIE

\section{Volume 8913}


The papers included in this volume were part of the technical conference cited on the cover and title page. Papers were selected and subject to review by the editors and conference program committee. Some conference presentations may not be available for publication. The papers published in these proceedings reflect the work and thoughts of the authors and are published herein as submitted. The publisher is not responsible for the validity of the information or for any outcomes resulting from reliance thereon.

Please use the following format to cite material from this book:

Author(s), "Title of Paper," in International Symposium on Photoelectronic Detection and Imaging 2013: Optical Storage and Display Technology, edited by Changsheng Xie, Yikai Su, Liangcai Cao, Proceedings of SPIE Vol. 8913 (SPIE, Bellingham, WA, 2013) Article CID Number.

ISSN: 0277-786X

ISBN: 9780819497826

Published by

SPIE

P.O. Box 10, Bellingham, Washington 98227-0010 USA

Telephone +1 3606763290 (Pacific Time) · Fax +1 3606471445

SPIE.org

Copyright @ 2013, Society of Photo-Optical Instrumentation Engineers.

Copying of material in this book for internal or personal use, or for the internal or personal use of specific clients, beyond the fair use provisions granted by the U.S. Copyright Law is authorized by SPIE subject to payment of copying fees. The Transactional Reporting Service base fee for this volume is $\$ 18.00$ per article (or portion thereof), which should be paid directly to the Copyright Clearance Center (CCC), 222 Rosewood Drive, Danvers, MA 01923. Payment may also be made electronically through CCC Online at copyright.com. Other copying for republication, resale, advertising or promotion, or any form of systematic or multiple reproduction of any material in this book is prohibited except with permission in writing from the publisher. The CCC fee code is 0277-786X/13/\$18.00.

Printed in the United States of America.

Publication of record for individual papers is online in the SPIE Digital Library.

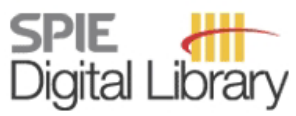

SPIEDigitalLibrary.org

Paper Numbering: Proceedings of SPIE follow an e-First publication model, with papers published first online and then in print and on CD-ROM. Papers are published as they are submitted and meet publication criteria. A unique, consistent, permanent citation identifier (CID) number is assigned to each article at the time of the first publication. Utilization of CIDs allows articles to be fully citable as soon as they are published online, and connects the same identifier to all online, print, and electronic versions of the publication. SPIE uses a six-digit CID article numbering system in which:

- The first four digits correspond to the SPIE volume number.

- The last two digits indicate publication order within the volume using a Base 36 numbering

system employing both numerals and letters. These two-number sets start with 00, 01, 02, 03, 04, $05,06,07,08,09,0 A, 0 B \ldots 0 Z$, followed by 10-1Z, 20-2Z, etc.

The CID Number appears on each page of the manuscript. The complete citation is used on the first page, and an abbreviated version on subsequent pages. Numbers in the index correspond to the last two digits of the six-digit CID Number. 


\section{Contents}

vii Conference Committee
ix Introduction

\section{OPTICAL STORAGE AND DISPLAY TECHNOLOGY}

891302 Bloch FDTD simulation of slow optical wave resonance cavity in optical storage technology [8913-3]

B. Zhang, Z. Lin, L. Cai, Changchun Institute of Optics, Fine Mechanics and Physics (China)

891303 Coherent single-detector 3D imaging system [8913-4]

J. Li, Y. Wang, R. Li, Y. Li, South China Normal Univ. (China)

891304 SIFT implementation based on GPU [8913-5]

C. Jiang, Z. Geng, X. Wei, C. Shen, Information Engineering Univ. (China)

891305 Collinear holographic data storage system (Invited Paper) [8913-7]

X. Tan, X. Lin, A. WU, Beijing Institute of Technology (China)

891306 The research for a system of city photonics map based on 3D holographic display technology [8913-8]

$X$. Jiang, Academy of Armored Force Engineering (China); P. Zhang, Academy of Armored Force Engineering (China) and Scientific Research Station of Unit 66393 (China); J. LV, Scientific Research Station of Unit 66393 (China); C. Pei, Academy of Armored Force Engineering (China)

891307 Space target detection in star image based on motion information [8913-12] J. Zhang, J. Ren, Naval Aeronautical and Astronautical Univ. (China); S. Cheng, People's Liberation Army (China)

891308 Multilayer optical storage for big data center: by pre-layered scheme (Invited Paper) [8913-13]

H. Ruan, Shanghai Institute of Optics and Fine Mechanics (China); C. Bu, Shanghai Institute of Optics and Fine Mechanics (China) and Graduate Univ. of the Chinese Academy of Sciences (China)

891309 Real-time arbitrary view synthesis method for ultra-HD auto-stereoscopic display [8913-17] Y. Cai, X. Sang, D. Chen, T. Zhao, X. Fan, N. Guo, X. Yu, B. B. Yan, Beijing Univ. of Posts and Telecommunications (China)

$89130 \mathrm{~A}$ Improvement of coding method for high vividness three-dimensional holographic imaging [8913-22]

J. Leng, Beijing Univ. of Posts and Telecommunications (China) and Beijing Information Science and Technology Univ. (China); X. Sang, B. Yan, M. Zhang, X. Cao, Beijing Univ. of Posts and Telecommunications (China) 
8913 OB Design of the control system for full-color LED display based on MSP430 MCU [8913-23] X. Li, Yanshan Univ. (China); H. Xu, Xingtai Vocational Technical College (China); L. Qin, Hebei Engineering Desing Consulting Co., Ltd. (China); L. Zheng, Yanshan Univ. (China)

8913 OC Denoising algorithm based on edge extraction and wavelet transform in digital holography [8913-24]

M. Zhang, X. Sang, J. Leng, X. Cao, Beijing Univ. of Posts and Telecommunications (China)

8913 OD Distance adaptive three-dimensional display based on mobile portable devices [8913-25] X. Jin, X. Sang, B. Yan, J. Yuan, Beijing Univ. of Posts and Telecommunications (China)

8913 OE Design of a system based on DSP and FPGA for video recording and replaying [8913-26]

Y. Kang, H. Wang, Wuhan Digital and Engineering Institute (China)

8913 OF Optical correlation recognition based on LCOS [8913-27]

M. Tang, J. Wu, Soochow Univ. (China)

$89130 \mathrm{~A}$ A real-time autostereoscopic display method based on partial sub-pixel by general GPU processing [8913-29]

C. Duo, X. Sang, Y. Cai, Beijing Univ. of Posts and Telecommunications (China)

$8913 \mathrm{OH} \quad$ Reconstruction of 3D scenes from sequences of images [8913-30]

B. Niu, X. Sang, D. Chen, Y. Cai, Beijing Univ. of Posts and Telecommunications (China)

89130 Ol Efficient spatiotemporal matching algorithm for stereo videos [8913-31]

X. Fan, X. Sang, N. Guo, D. Xu, Beijing Univ. of Posts and Telecommunications (China)

8913 0J Visual fatigue evaluation based on depth in 3D videos [8913-32]

F. Wang, X. Sang, Y. Liu, G. Shi, D. Xu, Beijing Univ. of Posts and Telecommunications (China)

8913 OK Synthesis and characterization of ZnTe thin films on silicon by thermal-furnace evaporation [8913-34]

J.-S. Lin, S.-S. Wei, Y.-T. Yu, C.-H. Hsu, W.-H. Kao, W.-S. Chen, C.-F. Tseng, C.-H. Lai, National United Univ. (Taiwan, China); J.-M. Lu, National Ctr. for High-Performance Computing (Taiwan, China); S.-P. Ju, National Sun Yat-Sen Univ. (Taiwan, China); J.-Y. Hsieh, Minghsin Univ. of Science and Technology (Taiwan, China)

$8913 \mathrm{OL} \quad$ New image fusion algorithm for auto-stereoscopic display [8913-35] C. Pan, Q. Yang, L. Xing, J. Li, Anhui Province Key Lab. for Modern Display Technology, State Special Display Engineering Lab. (China) and Avic Huadong Photoelectric Co.,Ltd, Shanghai (China)

$89130 \mathrm{M}$ The study of diffractive lenses displayed in a phase-only liquid crystal spatial light modulator [8913-39]

S. Ma, S. Panezai, D. Wang, Y. Wang, L. Rong, Beijing Univ. of Technology (China)

$8913 \mathrm{ON} \quad H i g h-i m m e r s i o n$ three-dimensional display of the numerical computer model [8913-40] S. Xing, X. Yu, T. Zhao, Y. Cai, D. Chen, Z. Chen, X. Sang, Beijing Univ. of Posts and Telecommunications (China) 
891300 A rapid iterative algorithm of obtaining wave-control data for liquid crystal phased array [8913-41]

J. Zhuo, L. Kong, Y. Zhou, J. Zhou, X. Yang, Univ. of Electronic Science and Technology of China (China)

8913 OP Design and fabrication of diffractive optical elements with complex profile by interference (Invited Paper) [8913-42]

J. Liu, R. Shi, H. Zhao, Y. Wang, Beijing Institute of Technology (China)

8913 OR Images fusion based on block compressed sensing and multiwavelet transform [8913-45]

S. Yang, Xi'an Univ. of Arts and Science (China); G. Wan, Northwestern Polytechnical Univ. (China); J. Gao, Xi' an Jiaotong Univ. (China); B. Zhang, Xi'an Univ. of Arts and Science

(China); X. Chong, Emerson Network Power Ltd. (China)

8913 OS Research of infrared laser based pavement imaging and crack detection [8913-46] H. Hong, S. Wang, X. Zhang, Wuhan Institute of Technology (China); G. Jing, National Ctr. of Metrization for Equipment of Roads and Bridges, Research Institute of Highways (China)

8913 OT The design of freeform surface lens for LED lighting system [8913-47]

Z. Bao, J. Zhu, S. Xiong, G. Jin, Tsinghua Univ. (China)

8913 OU Data processing method based on surface and tangent vector deviations for freeform surface [8913-51]

W. Hou, J. Zhu, T. Yang, G. Jin, Tsinghua Univ. (China)

$89130 \mathrm{~V}$ Distortion correction on numerical reconstruction of digital holography on arbitrarily tilted recording planes [8913-52]

J. Wang, W. Xiao, F. Pan, C. Gao, Beijing Univ. of Aeronautics and Astronautics (China)

8913 OW A green-color portable waveguide eyewear display system [8913-53]

L. Xia, K. Xu, Z. Wu, Y. Hu, Z. Li, Y. Wang, J. Liu, Beijing Institute of Technology (China)

8913 0X Overview of fast algorithm in 3D dynamic holographic display (Invited Paper) [8913-54]

J. Liu, J. Jia, Y. Pan, Y. Wang, Beijing Institute of Technology (China)

8913 OY Compressive sensing imaging with optical Fourier frequency spectrum coding and optical wavelet transform [8913-59]

J. Han, F. Xu, C. Wang, Soochow Univ. (China)

$89130 Z$ Blind restoration method of three-dimensional microscope image based on RL algorithm [8913-64]

J. Yao, S. Tian, X. Wang, J. Wang, Ningbo Dahongying Univ. (China)

891310 Three dimensional computer-generated holograms with shading effects based on a phase-only spatial light modulator [8913-69]

H. Zhang, Y. Zhao, L. Cao, G. Jin, Tsinghua Univ. (China)

891311 The E-O curve and phase shift of LCOS panel at different temperature and wavelength (Invited Paper) [8913-70]

S. Hong, E. Liao, M. Stover, Jasper Display Corp. (Taiwan, China); L.-Y. Liao, C.-H. Chen, National Tsing Hua Univ. (Taiwan, China) 
891312 Sensitivity of volume holographic optical computing [8913-72]

Y. Yi, L. Cao, T. Zheng, Tsinghua Univ. (China); W. Guo, People's Public Security Univ. of China (China); Q. He, G. Jin, Tsinghua Univ. (China)

891313 Image scale measurement with correlation filters in a volume holographic optical correlator (Invited Paper) [8913-73]

T. Zheng, L. Cao, Q. He, G. Jin, Tsinghua Univ. (China)

891314 A new algorithm for stripe noises detection and removal in image processing [8913-74]

J. Zhang, L.-Y. Xing, H.-L. Cui, Y. Yang, W.-Q. Wang, L. Liu, Jilin Univ. (China)

891315 Design of freeform surface lens for LED of random light distribution in road lighting [8913-75]

S. Xiong, J. Zhu, Z. Bao, G. Jin, Tsinghua Univ. (China)

Author Index 


\title{
Conference Committee
}

\author{
Conference Chairs
}

Konstantin Vodopyanov, Stanford University (United States) and CREOL, The College of Optics and Photonics, University of Central Florida (United States)

Guofan Jin, Tsinghua University (China)

Songlin Zhuang, University of Shanghai for Science and Technology (China)

Local Organizing Committee

Jiaqi Wang, Changchun Institute of Optics, Fine Mechanics and Physics (China)

Zuyan Xu, Technical Institute of Physics and Chemistry (China)

Zunqi Lin, Shanghai Institute of Optics and Fine Mechanics (China)

Dianyuan Fan, Shanghai Institute of Optics and Fine Mechanics (China)

Jingshan Jiang, Center for Space Science and Applied Research (China)

Liwei Zhou, Beijing Institute of Technology (China)

Shouhuan Zhou, North China Research Institute of Electro-optics (China)

Desheng Jiang, Wuhan University of Technology (China)

Jianquan Yao, Tianjin University (China)

Qingxi Tong, Institute of Remote Sensing and Digital Earth (China)

Junhao Chu, Shanghai Institute of Technical Physics (China)

Yongqi Xue, Shanghai Institute of Technical Physics (China)

Program Committee

Junhao Chu, Chair, Shanghai Institute of Technical Physics (China)

Jinxue Wang, Chair, Raytheon Company (United States)

Min Gu, Swinburne University of Technology (Australia)

Andreas Tünnermann, Friedrich-Schiller-Universität Jena (Germany)

Connie Chang, University of California, Berkeley (United States)

Shibin Jiang, AdValve Photonics Inc. (United States)

H. C. Liu, Shanghai Jiao Tong University (China)

Xiaocong Yuan, Nankai University (China)

Wei Shi, Tianjin University (China)

Min Qiu, Zhejiang University (China)

Nanjian Wu, Institute of Semiconductors (China) 


\section{Session Chairs}

$1 \quad$ Optical Storage and Display Technology

Mansuripur Masud, The University of Arizona (United States)

Changsheng Xie, Huazhong University of Science and Technology (China)

Yikai Su, Shanghai Jiao Tong University (China)

Liangcai Cao, Tsinghua University (China) 


\section{Introduction}

We have had the great honor of organizing the Fifth International Symposium on Photoelectronic Detection and Imaging (ISPDI) in Beijing. It was truly a great pleasure for us to greet the more than 1,200 participants from many different countries attending ISPDI 2013! I firmly believe that the symposium will become an important international event in the field of photoelectronic detection and imaging technology.

ISPDI 2013 was sponsored by SPIE, The Optical Society, European Optical Society, and the Chinese Society of Astronautics, and was organized by the Photoelectronic Technology Committee, Chinese Society of Astronautics, Tianjin Jinhang Institute of Technical Physics, Science and Technology on Low Light Level Night Vision Laboratory, Science and Technology on Optical Radiation Lab. and Science and Technology on Electromagnetic Scattering Lab. There were 26 cooperating organizations that supported the meeting. Nearly 850 papers were accepted for presentation at ISPDI 2013, contributed by over 1,370 authors from more than 10 countries, including the United States, United Kingdom, Germany, France, Norway, Australia, Canada, Japan, Korea, Russia, China, and so on. We had seven plenary speeches and 135 famous scientists and experts from home and abroad to present the invited talks at 10 different conferences.

The purpose of ISPDI 2013 is to provide a forum for the participants to report and review the innovative ideas and up-to-date progress and developments, and discuss the novel approaches to applications in the field of photoelectronic detection and imaging. It is sincerely hoped that the research and developments in optical and photoelectronic fields will be promoted, and that international cooperation and the sharing of common interests will be enhanced.

On behalf of Prof. Konstantin Vodopyanov, and the other conference chairs, and the Organization Committee of ISPDI, I would like to heartily thank our sponsors and cooperating organizations for all they have done for the meeting. Thanks also to all the authors for their contributions to the proceedings, to all of the participants and friends for their interest and efforts in helping us make the symposium possible, to the Program Committee for their effective work and valuable advice, and especially the ISPDI 2013 Secretariat and the SPIE staff for their tireless effort and outstanding service in preparing the meeting and publishing the conference proceedings.

Guofan Jin 